\title{
25 Carcinoid Tumor Cases Incidentally Detected After 4642 Appendectomies
}

\section{Apendektomi Sonrası İnsidental Olarak Saptanan 25 Karsinoid Tümör Olgusu}

\author{
(1) Yusuf Yavuz¹, (1) Mustafa Şentürk² \\ 1Şanlıurfa Training and Research Hospital, Clinic of General Surgery, Şanlıurfa, Turkey \\ ${ }^{2}$ Ceylanpınar City Hospital, Clinic of General Surgery, Şanlıurfa, Turkey
}

\section{IIIIIII| ABSTRACT}

Aim: This study aimed to retrospectively investigate 25 cases of carcinoid tumors in 4642 pathological examinations of patients who admitted to our clinic with acute appendicitis in a period of 6 years.

Method: 4642 appendectomy operations performed in Şanlıurfa Training and Research Hospital and Mehmet Akif İnan Training and Research Hospital between 2012 and 2019 were evaluated retrospectively. Data regarding age, sex, preoperative clinical findings, histopathological results, operation reports, follow-up period, and metastasis status were extracted from electronic records and reported.

Results: Based on the histopathological examination of 4642 patients admitted to the emergency department of two large hospitals of Sanlıurfa province, 25 patients were diagnosed with carcinoid tumors (neuroendocrine tumor). Thirteen of our patients were male and 12 of them were female. The mean age of our patients was 33.2 years. The mean follow-up period was 5-62 months. No distant metastasis was detected in any of the follow-ups of our patients who had histopathologically well-differentiated carcinoid tumors.

Conclusion: Carcinoid tumors are the most common tumors of the appendix, which are detected incidentally after an acute appendicitis operation. Since these tumors are rare, histopathological evaluation and postoperative follow-up are important. Though, in our study, it is not common in terms of rate, it is still important to follow up these cases since it is common in the young population, and there is a possibility of metastasis in advanced stages.

Keywords: Carcinoid tumor, appendix, incidental

\section{|HIIIIII| ÖZ}

Amaç: Çalışmamızın amacı kliniğimize 6 yıl içerisinde akut apandisit tanısı ile başvuran ve opere edilen 4642 patolojik incelemede bulunan 25 karsinoid tümör olgusunun retrospektif olarak incelenmesidir.

Yöntem: 2012 ile 2019 yılları arasında Şanlıurfa Eğitim ve Araştırma Hastanesi ve Mehmet Akif İnan Eğitim ve Araştırma Hastanesi’nde yapılan 4642 apendektomi operasyonu retrospektif olarak değerlendirildi. Yaş, cinsiyet, ameliyat öncesi klinik bulgular, histopatolojik sonuçlar, operasyon raporları, izlem süresi ve metastaz durumu elektronik ortamda incelenerek rapor edildi.

Bulgular: Şanlıurfa ilimizin iki büyük hastanesinde arasında acil servise başvuran ve apandektomi yapılan 4642 hastanın histopatolojik incelemesinde 25 hastaya karsinoid tümör (nöroendokrin tümör) tanısı konuldu. Hastalarımızdan 13’ü erkek 12 tanesi de bayan idi. Hastalarımızın yaş ortalaması 33,2 idi. Hastalarımızı ortalama takip süremiz 5-62 aydı. Histopatolojik olarak hepsinde iyi diferensiye karsinoid tümör rastlanan hastalarımızın takiplerinde hiçbirinde uzak metastaz tespit edilmemişti.

Sonuç: Karsinod tümörler çoğunlukla akut apandisit operasyonu sonrasında insidental olarak saptanan ve apendiksin en sık rastlanan tümörleridir. Bu tümörlerin az rastlanması nedeniyle histopatolojik değerlendirme ve operasyon sonrası takibi önem arz etmektedir. Bizim çalışmamızda oran olarak sık görülmese bile genç popülasyonda sık görülmesi ve ileri evrelerde metastaz ihtimali nedeniyle bu olguların yakın takibi önemlidir.

Anahtar Kelimeler: Karsinoid tümör, appendiks, insidental

Address for Correspondence/Yazışma Adresi: Yusuf Yavuz MD,

Sanlıurfa Training and Research Hospital, Clinic of General Surgery, Sanlıurfa, Turkey

Phone: +90 5414581778 E-mail: dryusufyavuz@hotmail.com ORCID ID: orcid.org/0000-0001-8031-2992

Received/Gelis Tarihi: 26.11.2019 Accepted/Kabul Tarihi: 19.12.2019

${ }^{\circ}$ Copyright 2020 by Turkish Society of Colon and Rectal Surgery

Turkish Journal of Colorectal Disease published by Galenos Publishing House. 


\section{Introduction}

Appendiceal tumors are among the less common tumors and these lesions are usually incidentally noticed after appendectomy. The incidence rate varies between 0.9 and $1 \%{ }^{1,2}$ Carcinoid tumors, also called neuroendocrine tumors, account for more than $50 \%$ of appendix tumors. They are generally more common in children and young adults. $3,4,5$ They are usually located at the tip of the appendix and most of the appendix carcinoids are smaller than $1 \mathrm{~cm}$ and rarely more than $2 \mathrm{~cm}$ in diameter. ${ }^{6}$ Although they are not frequently encountered after appendectomy operations, considering the number of appendectomies performed, it is important to follow up these cases that every general surgeon may face. Characteristics of patients histopathologically diagnosed with appendiceal carcinoid tumors were evaluated.

\section{Materials and Methods}

25 cases of carcinoid tumors detected after 4642 appendectomy operations performed in two major clinics in Şanlıurfa, Şanlıurfa Training and Research Hospital and Mehmet Akif İnan Training and Research Hospital between 2012 and 2019 were reviewed. The research was conducted following the principles of "World Medical Association Declaration of Helsinki: Ethical Principles for Medical Research Involving Human Subjects". Ethics committee approval was not received for this study because of its retrospective design. Informed consent was obtained from all patients. The age, sex, preoperative clinical findings, histopathological results, operation reports, follow-up period, and metastasis status of all cases were retrospectively analyzed thorough electronic records.

\section{Statistical Analysis}

Social Science Statistical Package (SPSS Inc., Chicago, IL, USA) software was used for bio-statistical analysis. When data were presented as mean values, standard deviation values were given and when they were presented as mean values, minimum $(\min )$-maximum $(\max )$ values were indicated.

\section{Results}

Thirteen of our patients were male and 12 were female. The mean age of our patients was 33.2 years (min-max=18-72). All of our patients were admitted to the emergency department for acute appendicitis and were operated for the diagnosis of acute appendicitis. As preoperative imaging examinations, 9 of our patients had ultrasonography (USG) and 10 had computed tomography (CT). 6 of our patients were operated with the preliminary diagnosis of acute appendicitis based on physical examination findings. The mean appendicitis diameter of patients who had any imaging examinations was $9.4 \mathrm{~mm}$ (min-max=3-20 mm) (Table 1). All appendecectomies performed in emergent setting. Symptoms such as diarrhea flushing in carcinoid syndrome were not apparent in our patients in the preoperative period. There were 2 patients with a tumor diameter greater than $20 \mathrm{~mm}$ and 8 patients with a tumor diameter of $10-20 \mathrm{~mm}$, and 15 patients with a tumor diameter less than $10 \mathrm{~mm}$. Two patients with a tumor diameter greater than $20 \mathrm{~mm}$ had undergone complementary right hemicolectomy, and tumor tissue was not found in the specimen examination afterward. Histopathologic examination revealed tumor localization in the distal appendix in 6 patients, proximal appendix in 18 patients; and in 1 patient multicentric mass was present in both distal and proximal appendix. No metastasis was detected in any of our patients. No complication was observed in the postoperative period during follow-up period of 42 months (min-max=5-62 months).

\section{Discussion}

Among the appendiceal malign tumors, carcinoid tumors are the most common. ${ }^{7}$ Apart from that, although rare, goblet cell carcinoma, lymphoma, mucocele, primary adenocarcinoma, and mucinous cystadenocarcinoma are also seen. ${ }^{8,9}$ In our study, the incidence of carcinoid tumors in patients with appendectomy was $0.53 \%$. In the literature, rates on this subject range from $0.3 \%$ to $0.9 \%$ and are slightly more common in women. ${ }^{5,10}$ However, in our study, 13 of our patients were male and 12 were female. Appendiceal carcinoid tumor is most commonly detected between 38 and 49 years of age. ${ }^{11}$ In our study, the mean age was 33.2 years and was lower than the literature. Appendiceal carcinoid tumors do not usually present with flushing and diarrhea-like symptoms which are signs of carcinoid syndrome. Carcinoid

Table 1. Clinical and demographic variables

\begin{tabular}{ll} 
Parameters & Cases (n, \%) \\
\hline Age, mean (SD) & $33.3 \pm 17.5$ \\
Diameter/mm, mean (SD) & $9.4 \pm 4.7$ \\
Follow-up/month, mean (SD) & $49.90 \pm 24$ \\
Gender & \\
\hline Male & $13(52 \%)$ \\
Female & $12(48 \%)$ \\
Tumor size & $8(32 \%)$ \\
$<10$ mm & $15(60 \%)$ \\
$10-20$ mm & $2(8 \%)$ \\
\hline $20>$ &
\end{tabular}

SD: Standard deviation 
syndrome which occurs due to vasoactive amine release is usually seen due to liver metastases. Tumors presenting with an acute appendicitis-like condition are incidentally diagnosed in postoperative preiod based on histopathologic findings. ${ }^{12}$ In our study, all of our patients were admitted to the emergency department with the diagnosis of acute appendicitis which is later confirmed histopathologically. In our patients who presented with acute appendicitis in the preoperative period, no pathology other than appendicitis was suspected macroscopically in this period. ${ }^{13}$ In our study, the rate of appendiceal carcinoid tumors, most of which were smaller than $1 \mathrm{~cm}$, was $56 \%$. In the literature, this rate was reported as $80 \%$. Tumors between 1 and $2 \mathrm{~cm}$ were $36 \%$ and tumors larger than $2 \mathrm{~cm}$ was $8 \%$. İn the literature, tumors of $1-2 \mathrm{~cm}$ were reported as $15 \%$ and tumors larger than $2 \mathrm{~cm}$ were reported as $5 \%$. Metastasis in appendiceal carcinoids is usually seen in tumors over $2 \mathrm{~cm}$, as a rare finding in ..$^{14,15,16,17}$ In the literature, rates up to $85 \%$ have been reported, but no patients with metastases were found in our study. Therefore, right hemicolectomy is recommended for the treatment of tumors larger than $2 \mathrm{~cm}$ due to the high probability of metastasis. Right hemicolectomy is recommended for treatment of cases with tumor size greater than $2 \mathrm{~cm}$. In cases with tumor smaller than $1 \mathrm{~cm}$, appendectomy is sufficient. Treatment in controversial cases with tumor size between 1 and $2 \mathrm{~cm}$ is under debate.

In such cases, including localized tumors at the base of the appendix, tumors with mucin production, tumors with high mitotic rate, childhood carcinoid tumors, serosa invasion, mesoappendix invasion, and lymphatic duct involvement, right hemicolectomy should be applied. ${ }^{16,18}$ While approximately $75 \%$ of appendiceal carcinoids are located proximal to the appendix, up to $10 \%$ are localized at the base. In our study, the tumor was at an apex in 17 (68\%) patients and radix in 7 (28\%) patients. One patient had a multicentric tumor at the base and proximal of the appendix (Table 2).

The rate of the synchronous or metachronous lesion was 13-33\% in the follow-up examinations of diagnosed patients. ${ }^{13,16,17,19}$ This shows the importance of colonoscopy in patients with carcinoid tumors. In our study, none of our patients were detected to have colorectal cancer. Colonoscopy requirement was reported to our patients.

Table 2. Location of tumor in the appendix

$\begin{array}{lll} & \text { Male }(\mathrm{n}=4) & \text { Female }(\mathrm{n}=4) \\ \text { Localization } & & \\ \text { Distal } & 4(16 \%) & 3(12 \%) \\ \text { Proximal } & 9(36 \%) & 8(32 \%) \\ \text { Distal + Proximal } & 0 & 1(4 \%)\end{array}$

The efficacy of effective chemotherapy in cases with metastasis was reported as $40 \%$ and the efficacy of radiotherapy in selected cases was reported as $60 \%$. The 5 -year survival was reported as $81 \%$ in cases with local metastasis and as $31 \%$ in cases with distant metastasis. ${ }^{11,19,20}$

\section{Conclusion}

In conclusion, appendiceal carcinoid tumors are usually incidentally detectable tumors.

\section{Ethics}

Ethics Committee Approval: Ethics committee approval was not received for this study because of its retrospective design.

Informed Consent: Informed consent was obtained from all patients.

Peer-review: Externally peer reviewed.

\section{Authorship Contributions}

Surgical and Medical Practices: Y.Y., M.Ş., Concept: Y.Y., Design: Y.Y., Data Collection or Processing: Y.Y., M.Ş., Analysis or Interpretation: M.Ş., Literature Search: M.Ş., Writing: Y.Y., M.S.

Conflict of Interest: No conflict of interest was declared by the authors.

Financial Disclosure: The authors declared that this study received no financial support.

\section{References}

1. Bulak H, Ozturk D, Ozcimen N, 1Kurca İ, Pekuysal M, Oral S. Apendiksin Neoplastik Lezyonları. T Klin J Med Sci 2004;24:271-276.

2. Hananel N, Powsner E, Wolloch Y. Primaryappendicealneoplasms. Isr J Med Sci 1993;29:733-734.

3. Pelizzo G, La Riccia A, Bouvier R, Chappuis JP, Franchella A. Carcinoid tumors of the appendix in children. Pediatr Surg Int 2001;17:399-402.

4. Pickhardt PJ, Levy AD, Rohrmann CA Jr, Kende AI. Primary neoplasms of the appendix manifesting as acute appendicitis: CT findings with the pathologic comparison. Radiology 2002;224:775-781.

5. Sandor A, Modlin IM. A retrospective analysis of 1570 appendiceal carcinoids. Am J Gastroenterol 1998;93:422-428.

6. Debnath D, Rees J, Myint F. Are we missing diagnostic opportunities in cases of carcinoid tumors of the appendix? Surgeon 2008;6:266-272.

7. Meşina C, Vasile I, Vilcea ID, Paşalega M, Calota F, Enache DS, Dumitrescu T, Mirea C, Mogoanta S. Carcinoid tumour of the appendix: problems of diagnosis and treatment. Chirurgia (Bucur) 2011;106:239-245.

8. Ma KW, Chia NH, Yeung HW, Cheung MT. If not appendicitis, then what else can it be? A retrospective review of 1492 appendectomies. Hong Kong Med J 2010;16:12-17.

9. Bucher P, Mathe Z, Demirag A, Morel P. Appendix tumors in the era of laparoscopic appendectomy. Surg Endosc 2004;18:1063-1066.

10. Mc Cusker ME, Cote TR, Clegg LX, Sobin LH. Primary malignant neoplasma of the appendix; a population based study from the surveillance, epidemiology and end-results program, 1973-1998. Cancer 2002; $94: 3307-3312$ 
11. In't Hof KH, van der Wal HC, Kazemier G, Lange JF. Carcinoid tumour of the appendix: an analysis of 1,485 consecutive emergency appendectomies. J Gastrointest Surg 2008;12:1436-1438.

12. Spallitta SI, Termine G, Stella M, Calistro V, Marozzi P. Carcinoid of the appendix. A case report.

13. Minerva Chir 2000;55:77-87.

14. Moertel CG, Weiland LH, Nagorney DM, Dockerty MB. Carcinoid tumor of the appendix: treatment and prognosis. N Eng J Med 1987;317:16991701.

15. Fornaro R, Frasciom, Sticchic AC, De Salvo L, Stabilini C, Mandolfino F, Ricci B, Gianetta E. Appendectomy on righthemicolectomy in thetreatment of appendiceal carcinoidtumors? Tumori 2007;93:587-590.

16. Celik F, Karsinoid tumorler. Kolon Rektum ve Anal Bolge Hastalıkları (Alemdaro.lu K, Akcal T, Bu.raD Eds), Ajans Plaza, Istanbul 2003;712-713.
17. Goede AC, Winslet MC. Surgery of carcinoidtumors of thelowergastrointestinaltract. Colorectal Disease 2003;123-126.

18. Modlin IM, Lye KD, Kidd M. A 5-decade analysis of 13715 carcinoid tumors. Cancer 2003;97:934-959.

19. Sweeney JF, Rosemurgy AS. Carcinoid Tumors of the Gut. Cancer Control 1997:4:18-24.

20. Bulak H, Öztürk D, Özçimen N, Kurca İ, Pekuysal M, Oral S. Neoplasms Of The Appendix Vermiformis. Turkiye Klinikleri J Med Sci 2004;24:271275

21. Üstünter MA, İlhan E, Üreyen O, Vardar E, Dalalı E, Gökçelli U, Tekeli MT, Güngör H, Kızanoğlu H. Surgical Approach According to The Tumor Size and Depth of Invasion in Carcinoid Tumors of Appendix: Case Report. Turkish Journal of Colorectal Disease 2015;25:63-67. 